\title{
Improving healthcare quality in the United States healthcare system: A scientific management approach
}

\author{
Soumya Upadhyay*1, William Opoku-Agyeman² \\ ${ }^{1}$ Department of Healthcare Administration and Policy, School of Public Health, University of Nevada Las Vegas, United States \\ ${ }^{2}$ School of Health and Applied Human Sciences, College of Health and Human Services, University of North Carolina \\ Wilmington, United States
}

Received: June 9, 2020

Accepted: September 26, $2020 \quad$ Online Published: October 28, 2020

DOI: $10.5430 /$ jha.v9n5p19

URL: https://doi.org/10.5430/jha.v9n5p19

\begin{abstract}
The US healthcare system has been facing pressures from stakeholders to reduce costs and improve quality. The purpose of this paper is to develop a conceptual model to illustrate the approaches used in healthcare quality management (Continuous Quality Improvement/Total Quality Management, Lean, and Six Sigma) weaved into the underlying framework of scientific management theory. This paper employs scientific management theory to explain the healthcare quality tenets that influence the quality of care in our healthcare organizations. The father of scientific management, Frederick Taylor, and other key contributors collectively created scientific management principles, which are widely used for quality improvement purposes both in the engineering and the healthcare field. Healthcare quality is also discussed with examples of the application of scientific management principles. Shared themes between scientific management principles and healthcare quality tenets, as given in CQI/TQM, Six Sigma-Lean, and Donabedian Model, were developed. To understand the three pillars of quality (structure, process, outcome) in relation to the underpinnings of scientific management principles, we incorporated insights of scientific management theory into Donabedian's healthcare quality model. It is recommended that selection of personnel play a more significant role among human resources practices in organizations; strategy formulation must include a careful assessment of organizations' strengths and weaknesses with regard to continuous quality improvement, with organizations striving to achieve standardization to attain efficiency and reduce costs.
\end{abstract}

Key Words: Scientific management, Healthcare quality, Donabedian, Taylor

\section{INTRODUCTION}

For several decades, the US healthcare system has been facing some issues regarding health care quality and inefficiencies. For instance, the Institute of Medicine (IOM) reported that, on average, between 44,000 and 98,000 patients die every year due to medical errors. ${ }^{[1]}$ A more recent study suggested that "medical error is the third leading cause of death in the US" accounting for over 400,000 inpatients deaths per year. ${ }^{[2]}$
In addition, the US has the highest administrative cost per capita and the highest national health expenditures compared with other developed countries. ${ }^{[3]}$ The estimated annual cost of waste in the US health care system ranges between $\$ 760$ to $\$ 935$ billion. ${ }^{[4]}$ Thus, Americans bear a significant burden in the form of lost lives, reduced functioning, wasted resources, and high costs. ${ }^{[5]}$

To address the rising healthcare costs, quality needs to be improved. ${ }^{[6]}$ To address the issues of health care quality

*Correspondence: Soumya Upadhyay, Ph.D.; Email: soumya.upadhyay@unlv.edu; Address: Department of Healthcare Administration and Policy, School of Public Health, University of Nevada Las Vegas, United States. 
and high costs, the IOM suggested that high-quality care should be safe, effective, patient-centered, timely, efficient, and equitable. ${ }^{[1]}$ In the same vein, the Institute for Healthcare Improvement issued the Triple Aim framework to tackle healthcare quality and costs. ${ }^{[7]}$ Furthermore, one of the objectives of the Affordable Care Act (ACA) is to improve health care quality while reducing costs. The ACA supports several national programs, such as the hospital value-based purchasing program, which contains four domains: safety, clinical care, efficient and cost reduction, and individual and community engagement. ${ }^{[8]}$

In response to pressures from stakeholders, hospitals are searching for ways to deliver more cost-effective and highquality care. This has led hospitals to apply the industrial quality control principles that deal with quality and costs in the provision of healthcare services. The industrial quality control principles initiated in the engineering field are better known as Continuous Quality Improvement (CQI) and Total Quality Management (TQM). Six Sigma and Lean methodologies are subsets of the CQI/TQM approach. Briefly, CQI/TQM includes vital elements of continuous improvement, customer focus, structured processes, and organizationwide participation. ${ }^{[9]}$ Six Sigma and Lean methodologies provide tools and techniques to measure and improve quality that are based on the scientific management theory. ${ }^{[10]}$ The hope is that widespread implementation of the underlying philosophy, approaches, and tools of CQI through Plan Do Check Act or Define Measure Analyze Improve Control cycles, TQM, and Lean management will result in cost reduction or containment coupled with improved quality. ${ }^{[9,11]}$ Additionally, the Malcolm Baldridge Excellence in Healthcare framework serves as a guide for attaining the highest quality level in health care. ${ }^{[12,13]}$

Thus, the purpose of this paper is to examine the broad area of healthcare quality through the conceptual lens of scientific management theory and provide a conceptual framework depicting the relationships between scientific management and healthcare quality improvement practices. We aim to understand how scientific management theory can enhance our efforts to find solutions for healthcare quality improvement. We hope that this paper will create a critical mass of thinking about healthcare quality built upon scientific management theory. This will provide a useful reference for researchers and benefit healthcare managers attempting to improve organizational efficiency and effectiveness through improved quality.

In the subsequent sections, we discuss the methodology, build a conceptual model, illustrate shared themes between scientific management principles and healthcare quality tenets, and provide an understanding of the pillars of Donabedian's quality framework concerning the underpinnings of scientific management principles. Finally, this paper will conclude by providing a summary and limitations and practice implications for future researchers and managers.

\section{CONCEPTUAL FRAMEWORK}

Scientific management is a collection of administrative theories and principles that were developed and introduced in the US between the 19th and 20th centuries. This period is significant in US history because it was in the middle of transitioning from an agrarian to an industrial economy. The scientific management era began during this transition. Frederick Taylor, who wrote the seminal book, Principles of Scientific Management, was the father of this era. ${ }^{[14]}$ Other key contributors of this era were Harington Emerson, Lilian Gilbreth, Hugo Munsterberg, Henry Gantt, and Edward Deming. ${ }^{[14-21]}$ Their collective efforts led to the creation of scientific management principles, which are widely used for quality improvement purposes, both in the engineering and the healthcare fields. ${ }^{[22,23]}$

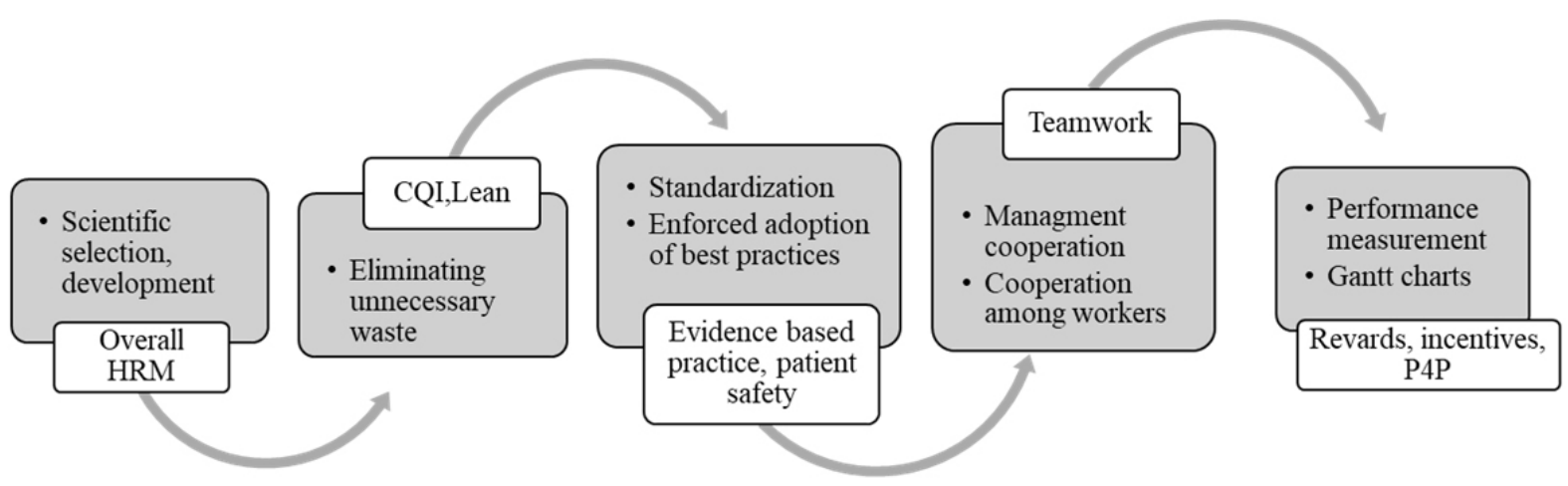

Figure 1. Flow chart of search results of studies from searching and screening 
Figure 1 illustrates a conceptual model that employs the essential constructs of scientific management theory to examine the tenets of healthcare quality. The illustration depicts certain key principles of the scientific methodology as the underlying roots for modern healthcare quality improvement tenets. The fundamental principles of scientific management are also intertwined, and all these principles are a part of the broader scientific management theory that has been explained in the introduction of this paper. These key principles are scientific selection, eliminating unnecessary waste, standardization, cooperation, and performance measurement.
Built upon these principles, are tenets of health care quality improvement, which are also intertwined, giving rise to the broader continuous quality improvement/total quality management methods. The key tenets of healthcare quality that were chosen for this paper and their corresponding scientific management theory are overall Human Resources Management (scientific selection, training, and development), continuous improvement and lean management (eliminating waste), evidence-based practice (standardization), teamwork (cooperation among workers) and rewards and incentives (performance measurement).

Table 1. Shared themes between scientific management principles and healthcare quality tenets as given in CQI/TQM, Six Sigma-Lean, and Donabedian Model

\begin{tabular}{|c|c|c|c|}
\hline Scientific management principles & $\begin{array}{l}\text { Healthcare quality improvement tenets } \\
\text { (as seen in CQI/TQM/Lean) }\end{array}$ & Techniques and tools & $\begin{array}{l}\text { Domain from } \\
\text { Donabedian model } \\
\text { for quality }\end{array}$ \\
\hline $\begin{array}{l}\text { - Scientific selection of employees } \\
\text { - Wellbeing of workers } \\
\text { - Employee welfare }\end{array}$ & $\begin{array}{l}\text { - Overall Human Resource Management } \\
\text { (HRM) } \\
\text { - Employee recruitment, satisfaction, } \\
\text { retention }\end{array}$ & HRM practices & Structure aspect \\
\hline $\begin{array}{l}\text { - Eliminating unnecessary waste } \\
\text { - Efficiency } \\
\text { - Cost reduction }\end{array}$ & $\begin{array}{l}\text { - Lean principles of reducing wasteful and } \\
\text { non-value adding processes } \\
\text { - Continuous improvement }\end{array}$ & Six Sigma and Lean methodology & $\begin{array}{l}\text { Process aspect } \\
\text { Outcome aspect }\end{array}$ \\
\hline $\begin{array}{l}\text { - Standardization of methods } \\
\text { - Reducing process variation }\end{array}$ & $\begin{array}{l}\text { - Standardization } \\
\text { - Benchmarking } \\
\text { - Evidence-based practices } \\
\text { - Patient focus }\end{array}$ & $\begin{array}{l}\text { Checklists, Pareto diagrams, } \\
\text { Statistical process control charts, } \\
\text { flow charts }\end{array}$ & Process aspect \\
\hline $\begin{array}{l}\text { - Cooperation } \\
\text { - Equal division of work } \\
\text { - Workers help each other }\end{array}$ & $\begin{array}{l}\text { - Teamwork } \\
\text { - Management cooperation } \\
\text { - Training }\end{array}$ & Brainstorming, Groupthink & Process aspect \\
\hline $\begin{array}{l}\text { - Performance measurement } \\
\text { - Bonus } \\
\text { - Rewards } \\
\text { - Incentives }\end{array}$ & $\begin{array}{l}\text { - Pay for performance } \\
\text { - Bonus } \\
\text { - Incentives, rewards }\end{array}$ & $\begin{array}{l}\text { Objective measures (clinical data) } \\
\text { Subjective measures } \\
\text { (patient and employee surveys) } \\
\text { Employee performance appraisals } \\
\text { Financial data } \\
\text { Complaints data }\end{array}$ & Outcome aspect \\
\hline
\end{tabular}

Healthcare researchers and practitioners alike should benefit from an understanding of the theoretical framework behind healthcare quality. Theory development of healthcare quality should stimulate empirical research. For healthcare practitioners, theory development can help differentiate between successful and unsuccessful efforts. ${ }^{[5]}$

\section{SHARED THEMES BETWEEN SCIENTIFIC MANAGEMENT PRINCIPLES AND HEALTH- CARE QUALITY TENETS}

Table 1 shows a matrix that is based on the conceptual model above. This table shows the shared themes between principles of scientific management and tenets of healthcare quality, as seen in CQI/TQM and Lean Six Sigma. It also presents the tools and techniques that can be used by practitioners to im- prove healthcare quality within their organizations. Finally, it indicates the corresponding domains of Donabedian's model for quality as they relate to those common themes. ${ }^{[24]}$

\subsection{Scientific employee selection, employee welfare, em- ployee satisfaction [overall Human Resources Man- agement (HRM)]}

Regarding overall Human Resources Management, Taylor suggests a careful selection of employees. He insists on "scientifically selecting, training and developing the employee, whereas in the past the employee chose his/her work or trained him/herself the best they could. With training, each employee becomes skilled in his/her trade than it is possible for anyone to be". ${ }^{[14]}$ This is applicable to nurse and physician selections in the healthcare system. Their education, 
training, and recruitment are a combination of overall Human Resources Management. The Malcolm Baldridge National award is an indicator of high-quality performance, which was created by the US government in 1987 to recognize quality excellence and to stimulate quality improvement in the healthcare industry. ${ }^{[12]}$ According to Dean and Bowens, the HRM areas identified by the Malcolm Baldridge National Quality award frequently used in management theory are human resources planning, employee involvement, employee education, and training, employee performance and recognition, and employee wellbeing and satisfaction. ${ }^{25]}$

One area that is emphasized in Emerson's seminal book "Efficiency as the basis for operations and wages" consists of employee wellbeing and satisfaction. ${ }^{[26]}$ Emerson, indicated that an "organization's executives should select workers, prepare them, maintain them in a happy, healthful condition. Then outline for them tasks that will be pleasurable, not repugnant, and exhausting." Overworked clinicians may lead to burnout and exhaustion, which in turn may lead to adverse medical events and patient safety issues. ${ }^{[27]}$ Also, maintaining clinicians and other staff in a happy environment and taking care of their wellbeing is crucial for the success of a healthcare organization. ${ }^{[28]}$

\subsection{Elimination of unnecessary waste/efficiency/cost re- duction}

Emerson claims three things relating to efficiency: (1) the cost of the product or service could be reduced by eliminating waste, (2) employees could work one-third of the time and achieve just as much, and (3) one employee could do all of the work and earn three times as much. ${ }^{[26]}$ In the same vein, Donabedian defines seven attributes of healthcare quality as efficacy, effectiveness, efficiency, optimality, acceptability, legitimacy, and equity. Efficiency is the ability to obtain the greatest health improvement at the lowest cost. ${ }^{[29]}$ Unfortunately, there are inefficiencies in the healthcare system, as discussed in previous sections. Improvement in healthcare quality can only be achieved by continuously improving processes, eliminating non-value adding steps and wastes, and increasing efficiency to reduce costs. Lean management is a practice that organizations can use to increase efficiency and reduce waste. ${ }^{[30]}$ Lean methods are used both in the production and service industry by the elimination of unnecessary waste and non-value adding processes. ${ }^{[6,31]}$

\subsection{Standardization of methods/reducing process varia- tion}

Leaders of scientific management have recommended the adoption of the best standardization of methods. Taylor asserts that management must enforce the adoption of stan- dards. ${ }^{[14]}$ Emerson also recommends that all standard policies and procedures be followed so that all employees may understand the goals, reprimanding all deviations. ${ }^{[26]}$ Munsterberg reiterates the importance of reduction in process variation by noting that the psychology of human variations gives an account of the differences from person to person. ${ }^{[32]}$ In other words, from a healthcare perspective, different healthcare professionals could interpret the same concept/procedure in different ways.

Resar confirms Taylor's and Munsterberg's observation; training new employees and testing current employees for competence are both tough to establish and maintain when the process on which they are supposed to be trained are highly variable. ${ }^{[33]}$ Even though Resar asserts that standardization is the most crucial tactic to prevent common failures such as "lack of a defined process"; ${ }^{[33]}$ Hales and Pronovost argue that, operationally, it is very difficult to standardize processes in medicine due to unforeseen adverse events, concomitant factors and unpredictable human factors that can influence the approach to treatment. ${ }^{[34]}$ Tools used for reduction in process variation (Pareto diagrams, statistical process control charts) and tools for standardization (checklists) have been seen to ensure that performance and patient safety standards are met. ${ }^{[17]}$

\subsection{Teamwork/management cooperation/training}

Teamwork, management cooperation, and training are also essential components of quality improvement. Taylor suggests that to obtain significant and positive results, employees and management need to cooperate and equally divide responsibilities among themselves. ${ }^{[14]}$ In the modern healthcare quality area, a founding principle of total quality management is teamwork, since dysfunctional team dynamics has, been suggested to be the cause of more than $70 \%$ of medical errors.

However, Clancy and Tornberg indicated that health professional training has historically been isolated within specific disciplines. ${ }^{[16]}$ For instance, nurses are trained to work as managers of situations. However, physicians bear the ultimate responsibility of "leading" treatment situations. This may lead to both broken team dynamics and misdiagnoses. Therefore, to reduce medical errors, teamwork has become the focus of increased attention in healthcare. As a result, Agency for Healthcare Quality (AHRQ), in collaboration with the Department of Defense (DoD), developed the Team Strategies and Tools to Enhance Performance and Patient Safety (TeamSTEPPS $R$ ), which is the flagship team training program for healthcare organizations for a better resource for training healthcare providers in better interprofessional teamwork practices, called TeamSTEPPS. ${ }^{[35]}$ Several stud- 
ies have demonstrated the effectiveness of TeamsTEPPS in fostering teamwork and collaboration. ${ }^{[36]}$ Also, when individual and organizational learning happens in the context of a well-functioning team, there is an increase in healthcare quality and patient safety. ${ }^{[37]}$ Tenets of scientific management tell us that management support, teamwork, and training are all essential components of an organization's effective administration.

3.5 Performance measurement/bonus/rewards/incentives One of the key contributors to scientific management, Henry Gantt, suggested the use of useful measurement and planning to increase productivity. He developed the Gantt chart to manage a complex project by breaking it into its parts, then scientifically studying, optimizing and synthesizing the best way to complete the project as a whole. ${ }^{[18]}$ In healthcare, performance measurement systems are used as a six-sigma quality improvement procedure, one of which consists of the "measure" phase that determines performance standards, collects data, and assesses process capability.

A seminal quote by Gantt: "Not what we have but what we can do is more important." suggests that rewards must be based on services rendered. ${ }^{[38]}$ Also, Gantt advises that there should be some means of measuring and recording the worker's results. Gantt's system interlinked the rewards paid to the supervisor with the rewards paid to the workers- he wanted a win-win outcome for everyone. The primary focus of his charts is to show the differences between projected and actual performances. ${ }^{[39]}$ Similarly, Emerson and Gilbreth propose maintaining records to compare performances. ${ }^{[19,26]}$ Taylor suggests that rewards should immediately follow outstanding performances to motivate employees to perform better. ${ }^{[14]}$ Thus, Gilbreth indicates incentives as one of the underlying ideas of scientific management and emphasizes that rewards work as incentives for employees. ${ }^{[19]}$ Indeed, prior studies have demonstrated the importance of rewards and their effectiveness in employee retention, job satisfaction, and quality of care. ${ }^{[40-43]}$

\subsection{Scientific management principles as they relate to donabedian's quality model}

We incorporated the Donabedian's quality model into the framework of common themes between scientific management principles and healthcare. The framework for healthcare quality called Structure-Process-Outcome was developed by Donabedian in 1996 and is used primarily in health care quality research. ${ }^{[24]}$

The first component consists of "Structure of Care", which is defined as care settings. Settings include both the physical and organizational aspects of care, such as facilities, equipment, personnel, operational and financial processes supporting medical care. ${ }^{[24]}$ The second component is the "Processes of care", which is defined as the actual delivery of health care services, lies in between structure of care and outcomes. Processes depend on a structure to obtain the resources needed first to execute procedures for care delivery and then deliver health outcomes. These processes include patient care activities that are performed in order to achieve the third component "Outcomes", which include improvement in patient health, promotion of recovery, prevention of diseases and illnesses, functional restoration, survival from death, and even patients' and their families' satisfaction. Donabedian posits that a health care organization that has a high-quality structure can deliver high-quality care process, which leads to positive patient outcomes. ${ }^{[24]}$

Table 1 depicts the domains of Donabedian's quality framework that applies to common themes between scientific management principles and healthcare quality tenets. Selection of employees, their wellbeing, satisfaction and recruitment fall under the structure part of Donabedian's model because employees support medical care. Eliminating unnecessary waste, enhancing process efficiency, standardizing methods, and reducing process variation apply to the process and outcome aspects of this framework. Standardization of processes and reducing within-process variations leads to better outcomes in the form of better clinical care. Cooperation among teams, management support, and teaching are crucial parts of the process of care because efficient teamwork and effective management style improve processes. Finally, performance measurement is included within the outcome of care because performances are outcomes, and their measurements (keeping records and rewarding good performances) are imperative to improving the quality of care.

\section{Conclusions}

Scientific management has shown a profound impact on quality improvement both in the industrial and healthcare organizations. The principles of scientific management have helped in building the tools and methods that can be effectively used for quality improvement purposes. The objective of this conceptual paper was to identify areas in which the healthcare quality perspective is based on scientific management theory to a large extent. To accomplish this goal, we provided a conceptual framework that identifies the common threads between scientific management principles and healthcare quality tenets and demonstrates the close connection between healthcare quality and scientific management prescriptions. Human Resources Management (HRM) practices include scientifically selecting, training and developing the employees, staying conscious of their wellbeing, and main- 
taining their satisfaction, which impacts healthcare quality.

Eliminating non-value-added processes helps increase efficiency and reduce costs resulting in a better quality of care. Reducing variation and standardizing processes are forms of quality improvement methodology to maintain consistency and improve quality. Teamwork, cooperation by management, and efforts to train and lead healthcare providers to follow proper directions, reduce the number of errors performed, and provide a higher quality of care.

Performance measurement, rewards, and incentives encourage nurses, physicians, and other healthcare providers to improve the quality of care they deliver. Finally, Donabedian's framework for quality was incorporated into the scientific management principles, and each theme was related to a domain of the Donabedian's model.

Given the relationship that quality improvement in healthcare has with scientific management principles, it is evident that future healthcare quality can be improved further by developing methodologies and tools based on these principles. For example, stakeholders that are interested in finding solutions to healthcare quality issues can focus on specific aspects of scientific management that have not been explored in detail yet. Some examples include functionalization, individuality, analysis, and synthesis. ${ }^{[19]}$

Limitations of this article include the failure to map every aspect of scientific management with those of healthcare quality and vice-versa. Future studies can expand this paper by discussing a more significant number of underlying ideas and principles of the scientific management theory as they fit into the quality improvement tenets. Similarly, a broader scope of health quality improvement principles, other than just CQI/TQM and lean, can be studied as an extension of scientific management theory and cater to a broader audience of health professionals and policymakers.

The implementation of CQI/TQM, lean, and practice of management, in general, can be enhanced by incorporating insights of scientific management theory. Practical implications include:

- Selection (recruitment, retention, training) should play a more prominent role among HR practices in organizations, especially concerning person-organization fit.

- Strategy formulation should be built around continuous quality improvement and must include an assessment of organizations' strengths and weaknesses.

- Organizations must strive to achieve standardization within processes and reduce variation to achieve efficiency and reduce costs.

\section{ACKNOWLEDGEMENTS}

We will like to acknowledge all the reviewers who have helped in the preparation of this research paper through several rounds of revisions.

\section{CONFLiCTS OF INTEREST DisClosure}

The authors declare they have no conflicts of interest.

\section{REFERENCES}

[1] Donaldson MS, Corrigan JM, KohnLT. To err is human: building a safer health system. National Academies Press; 2000.

[2] Makary MA, Daniel M. Medical error-the third leading cause of death in the US. BMJ. 2016; 353: i2139. PMid: 27143499. https : //doi.org/10.1136/bmj.i2139

[3] Himmelstein DU, Jun M, Busse R, et al. A comparison of hospital administrative costs in eight nations: US costs exceed all others by far. Health Affairs. 2014; 33(9): 1586-1594. PMid: 25201663. https://doi.org/10.1377/hlthaff .2013.1327

[4] Shrank WH, Rogstad TL, Parekh N. Waste in the US health care system: estimated costs and potential for savings. JAMA. 2019; 322(15): 1501-1509. PMid: 31589283. https ://doi.org/10.1001/jama .2019 .13978

[5] Chassin MR, Galvin RW. The urgent need to improve health care quality: Institute of Medicine National Roundtable on Health Care Quality. JAMA. 1998; 280(11): 1000-1005. PMid: 9749483. https : //doi.org/10.1001/jama.280.11.1000

[6] James BC, Savitz LA. How Intermountain trimmed health care costs through robust quality improvement efforts. Health Affairs. 2011;
30(6): 1185-1191. PMid: 21596758. https://doi.org/10.137 7/hlthaff.2011.0358

[7] Berwick DM, Nolan TW, Whittington J. The triple aim: care, health, and cost. Health Affairs. 2008; 27(3): 759-769. PMid: 18474969. https://doi .org/10.1377/hlthaff .27.3.759

[8] Ryan AM, Krinsky S, Maurer KA, et al. Changes in hospital quality associated with hospital value-based purchasing. New England Journal of Medicine. 2017; 376(24): 2358-2366. PMid: 28614675. https://doi.org/10.1056/NEJMsa1613412

[9] Shortell SM, O'Brien JL, Carman JM, et al. Assessing the impact of continuous quality improvement/total quality management: concept versus implementation. Health Services Research. 1995; 30(2): 377

[10] TrakulsuntiY, Antony J. Can Lean Six Sigma be used to reduce medication errors in the health-care sector? Leadership in Health Services. 2018; 31(4): 426-433. PMid: 30234447. https ://doi.org/10.1 108/LHS-09-2017-0055

[11] Al-Araidah O, Momani A, Khasawneh M, et al. Lead-time reduction utilizing lean tools applied to healthcare: The inpatient pharmacy at a local hospital. Journal for Healthcare Quality. 2010; 32(1): 5966. PMid: 20151593. https ://doi.org/10.1111/j.1945-147 4.2009.00065.x 
[12] Garvin DA. How the Baldrige Award really works. Harvard Business Review. 1991; 69(6): 80-95.

[13] Goonan KJ, Muzikowski JA, Stoltz PK. Journey to excellence: How Baldridge health care leaders succeed. ASQ Quality Press Milwaukee; 2009.

[14] Taylor FW. The principles of scientific management. Harper \& Brothers; 1919.

[15] Emerson H. Efficiency as a Basis for Operation and Wages. Engineering magazine Company; 1919.

[16] Churchill GA Jr. A paradigm for developing better measures of marketing constructs. Journal of Marketing Research. 1979; 16(1): 64-73. https://doi.org/10.1177/002224377901600110

[17] Leape LL, Berwick DM, Bates DW. What practices will most improve safety?: evidence-based medicine meets patient safety. JAMA. 2001; 288(4): 501-507. PMid: 12132984. https://doi.org/10 $.1001 / \mathrm{jama} .288 .4 .501$

[18] Gantt HL. Work, wages, and profits. Engineering magazine. 1913.

[19] Gilbreth LM. The psychology of management: The function of the mind in determining, teaching and installing methods of least waste. Sturgis \& Walton Company; 1914.

[20] Deming WE. The new economics for industry, government, education. MIT Press; 2018. https://doi .org/10.7551/mitpress/1 1458.001 .0001

[21] Deming WE. Out of the crisis. Ed: Massachusetts, USA: MIT Press; 2000.

[22] Baumgart A, Neuhauser D. Frank and Lillian Gilbreth: scientific management in the operating room. Ed: BMJ Publishing Group Ltd.; 2009. PMid: 19812107. https://doi.org/10.1136/qshc. 200 9.032409

[23] Villa S, Restuccia JD, Anessi-Pessina E, et al. Quality improvement strategies and tools: A comparative analysis between Italy and the United States. Health Services Management Research. 2018; 31(4): 205-217. PMid: 29486603. https://doi.org/10.1177/095148 4818755534

[24] Donabedian A. Evaluating the quality of medical care. The Milbank Memorial Fund Quarterly. 1966; 44(3): 166-206. https: //doi.org/10.2307/3348969

[25] Dean JW Jr., Bowen DE. Management theory and total quality: improving research and practice through theory development. Academy of Management Review. 1994; 19(3): 392-418. https ://doi.org/ $10.5465 / \mathrm{amr} .1994 .9412271803$

[26] Emerson H. Efficiency as a Basis for Operation and Wages. 4th ed. Easton, PA: Hive Publishing; 1976/1908.

[27] Salyers MP, Bonfils KA, Luther L, et al. The relationship between professional burnout and quality and safety in healthcare: a metaanalysis. Journal of General Internal Medicine. 2017; 32(4): 475-482. PMid: 27785668. https://doi.org/10.1007/s11606-016-3 886-9

[28] Mardeen A, Brenda S, Rajshekhar G. Happy Employees Lead To Loyal Patients, Survey of nurse and patients shows a strong link between employee satisfaction and patient loyalty. Journal of Health Care Marketing. 1995; 16-23.

[29] Donabedian A. The seven pillars of quality. Archives of Pathology \& Laboratory Medicine. 1990; 114(11): 1115-1118.

[30] Teich ST, Faddoul FF. Lean management-the journey from Toyota to healthcare. Rambam Maimonides Medical Journal. 2013; 4(2). PMid: 23908857. https://doi.org/10.5041/RMMJ . 10107

[31] D'Andreamatteo A, Ianni L, Lega F, et al. Lean in healthcare: A comprehensive review. Health Policy. 2015; 119(9): 1197-1209. PMid: 25737260. https://doi.org/10.1016/j.healthpol.2015.0 2.002

[32] Munsterberg H. Psychology and industrial efficiency. A\&C Black; 1998.

[33] Resar RK. Making noncatastrophic health care processes reliable: Learning to walk before running in creating high-reliability organiations. Health Services Research. 2006; 41(4): 1677-1689. PMid: 16898985. https://doi.org/10.1111/j.1475-6773.2006.0 0571. $\mathrm{x}$

[34] Hales BM, Pronovost PJ. The checklist-a tool for error management and performance improvement. Journal of Critical Care. 2006; 21(3): 231-235. PMid: 16990087. https://doi.org/10.1016/j.jcrc .2006 .06 .002

[35] Clancy CM, Tornberg DN. TeamSTEPPS: assuring optimal teamwork in clinical settings. American Journal of Medical Quality. 2007; 22(3): 214-217. PMid: 17485563. https://doi.org/10.1177/ 1062860607300616

[36] Chen AS, Yau B, Revere L, et al. Implementation, evaluation, and outcome of TeamSTEPPS in interprofessional education: a scoping review. Journal of Interprofessional Care. 2019; 1-10. PMid: 31009273. https://doi.org/10.1080/13561820.2019.1594729

[37] Firth-Cozens J. Cultures for improving patient safety through learning: the role of teamwork. BMJ Quality \& Safety. 2001; 10(suppl 2): ii26-ii31. PMid: 11700376. https://doi.org/10.1136/qhc.01 00026

[38] Gantt HL. Organizing for work. Harcourt, Brace and Howe. 1919.

[39] Weaver P, Gantt HL. 1861-1919 Debunking the myths, a retrospective view of his work. PM World Journal. 2012; 1(5).

[40] Young CM, Albert NM, Paschke SM, et al. The 'Parent Shift' program: incentives for nurses, rewards for nursing teams. Nursing Economics. 2007; 25(6): 339-345.

[41] Leveck ML, Jones CB. The nursing practice environment, staff retention, and quality of care. Research in Nursing \& Health. 1996; 19(4): 331-343. https://doi .org/10.1002/(SICI) 1098-240 X (199608) 19:4<331: : AID-NUR7>3.0.CO;2-J

[42] Lindenauer PK, Remus D, Roman S, et al. Public reporting and pay for performance in hospital quality improvement. New England Journal of Medicine. 2007; 356(5): 486-496. PMid: 17259444. https://doi.org/10.1056/NEJMsa064964

[43] Petersen LA, Woodard LD, Urech T, et al. Does pay-for-performance improve the quality of health care? Annals of Internal Medicine. 2006; 145(4): 265-272. PMid: 16908917. https://doi.org/10 .7326/0003-4819-145-4-200608150-00006 